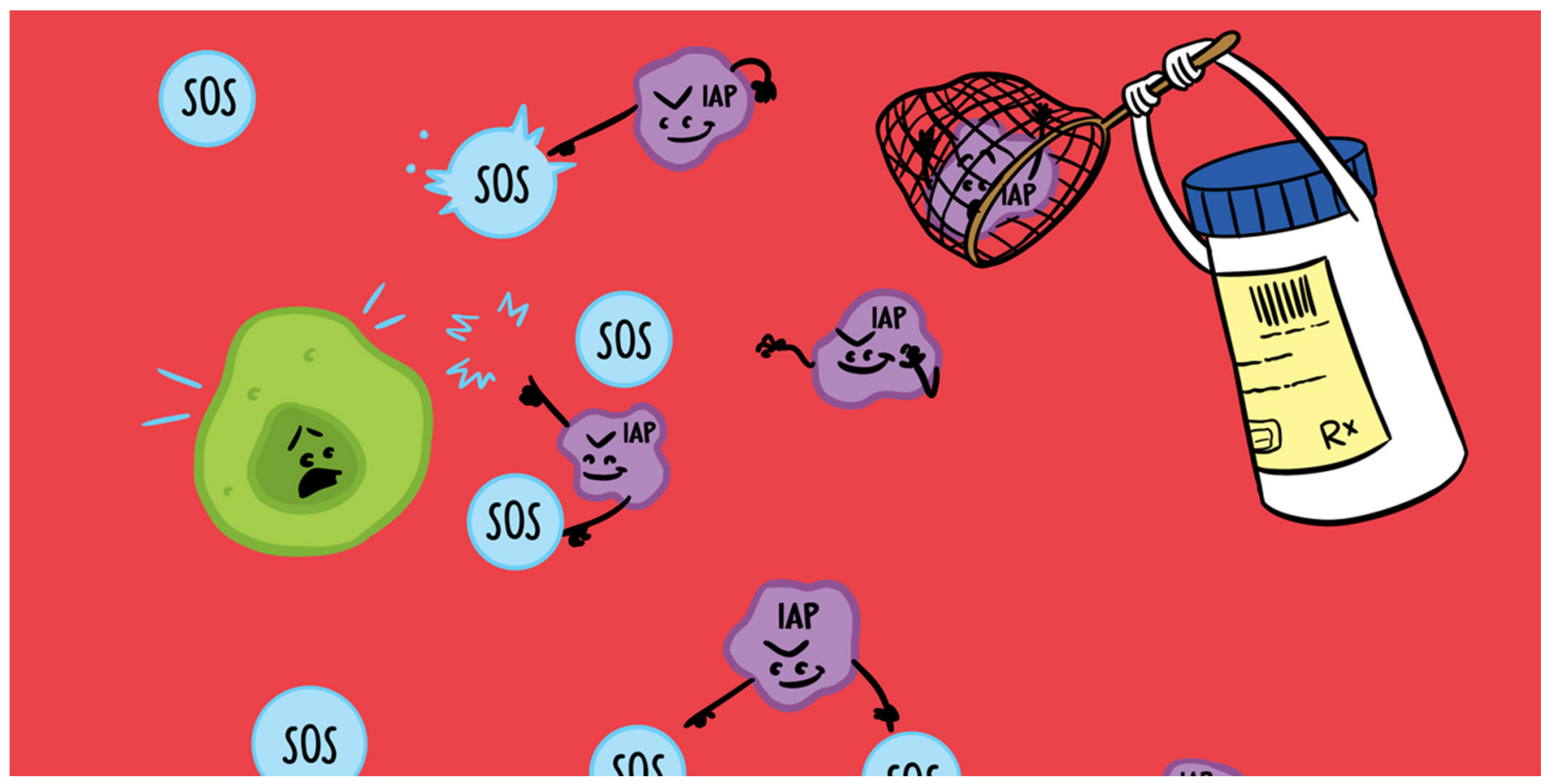

\title{
TEST OF A NEW DRUG TO TREAT BRAIN CANCER
}

\section{Aurélie Soubéran*}

CNRS, INP, Institut de Neurophysiopathologie, Aix-Marseille Univ, Marseille, France

YOUNG REVIEWER:

ELIZA
age: 12

You may never have heard it, but there is a rare but aggressive brain cancer called "glioblastoma." Its name is as complicated as finding a drug to destroy it! Usually, when cells realize that they are getting sick, they are able to send distress messages and can self-destruct before they evolve into disease. Unfortunately, glioblastoma cancer cells are extremely intelligent; they send a lot of small molecules ("the BLOCKERS") to intercept these messages. With this scheme, cancer cells become immortal; they can reproduce themselves and spread throughout the whole brain. So, researchers have been looking into this problem to try to find a new drug that can catch these BLOCKERS. We studied a potential therapeutic drug that catches these small molecules and locks them up, which allows the cancer cells to destroy themselves. Excitingly, we found that this drug is able to fight glioblastoma in mice!

Do you know how many cells make up your body? You would not believe it ... about a hundred thousand billion! The body is an incredible machine; it controls all these little pieces so that it works properly every day. All our cells have a very precise role, forming organs like the 


\section{APOPTOSIS}

Apoptosis (or programmed cell death) is the process by which cells initiate their self-destruction in response to a signal.

\section{GLIOBLASTOMA}

Glioblastoma is a tumor that develops in the brain. It is caused by the abnormal proliferation of sick cells of the brain.

\section{IAPS}

Inhibitors of apoptosis (IAPs) are a group of proteins that block programmed cell death which can frequently lead to cancer. brain, for example. Sometimes some cells transform, which means they undergo mutations (a bit like ninja turtles) and start doing nonsense. It happens every day to everyone. When these mutant cells become too numerous in an organ, it looks like cancer. But then the question is, why does not everyone develop cancer if some cells transform all the time?

Our cells have an alarm system that triggers when they become sick and harmful to the body. These sick cells send emergency signals, like an S.O.S., telling the body to set up its defense. This phenomenon is called "apoptosis," which is a process of self-destruction, or programmed suicide, of cells. Most of the time this alarm system works perfectly, but there are exceptions, like in the brain cancer known as glioblastoma. Glioblastoma is a rare cancer with "only" 250,000 new cases worldwide each year. Unfortunately, it is also an aggressive cancer and to date we do not know how to cure patients suffering from glioblastoma [1]. However, remember that every day, research makes advances in cancer treatments. Today, we know how to treat many types of cancer, such as breast cancer, so that patients can go on to live long lives.

\section{THE GLIOBLASTOMA COUNTERATTACK}

Glioblastoma cells develop ingenious mechanisms to escape apoptosis, including the production of molecules called IAPs, which we will call "the BLOCKERS." The BLOCKERS are present in all cells to help them survive, but they are more numerous in cancer cells! In glioblastoma, the BLOCKERS intercept the S.O.S signals from the cancer cells, so that these cells cannot self-destruct. The BLOCKERS also prevent the immune system from seeing the cancer settling into the brain. In order to counter these dangerous activities of the BLOCKERS, chemists have created a drug that should have the ability to bind to the BLOCKERS to neutralize them [2]. This way, the S.O.S signals send by the first cancer cells will reach the appropriate targets and the cancer cells will be destroyed (Figure 1).

\section{HOW DID WE TEST THE NEW DRUG?}

Biologists (people who study living things) take over from chemists in order to test the anti-cancer power of a new drug. For our drug, the study was carried out in two stages: an in vitro part, which means that we did experiments with the drug using cells in test tubes, and an in vivo part, where we studied the effect of the drug on animals. For the in vitro studies, we used human cancer cells. The principle is simple we recover a piece of a tumor (mass of cancer cells) from a cancer 
Figure 1

Glioblastoma is a brain cancer that most often affects the elderly. In the top panel, you can see that glioblastoma consists of cancer cells mixed with some normal cells. In the bottom panel, normal cells undergo mutations (yellow lightnings) that transform them into cancer cells that have a lot of BLOCKERS (red/ black points). Most of the time, sick cells are ordered to selfdestruct. In the case of glioblastoma, the BLOCKERS intercept that S.O.S messages (like a net), allowing the cancer cells to stay alive and spread.

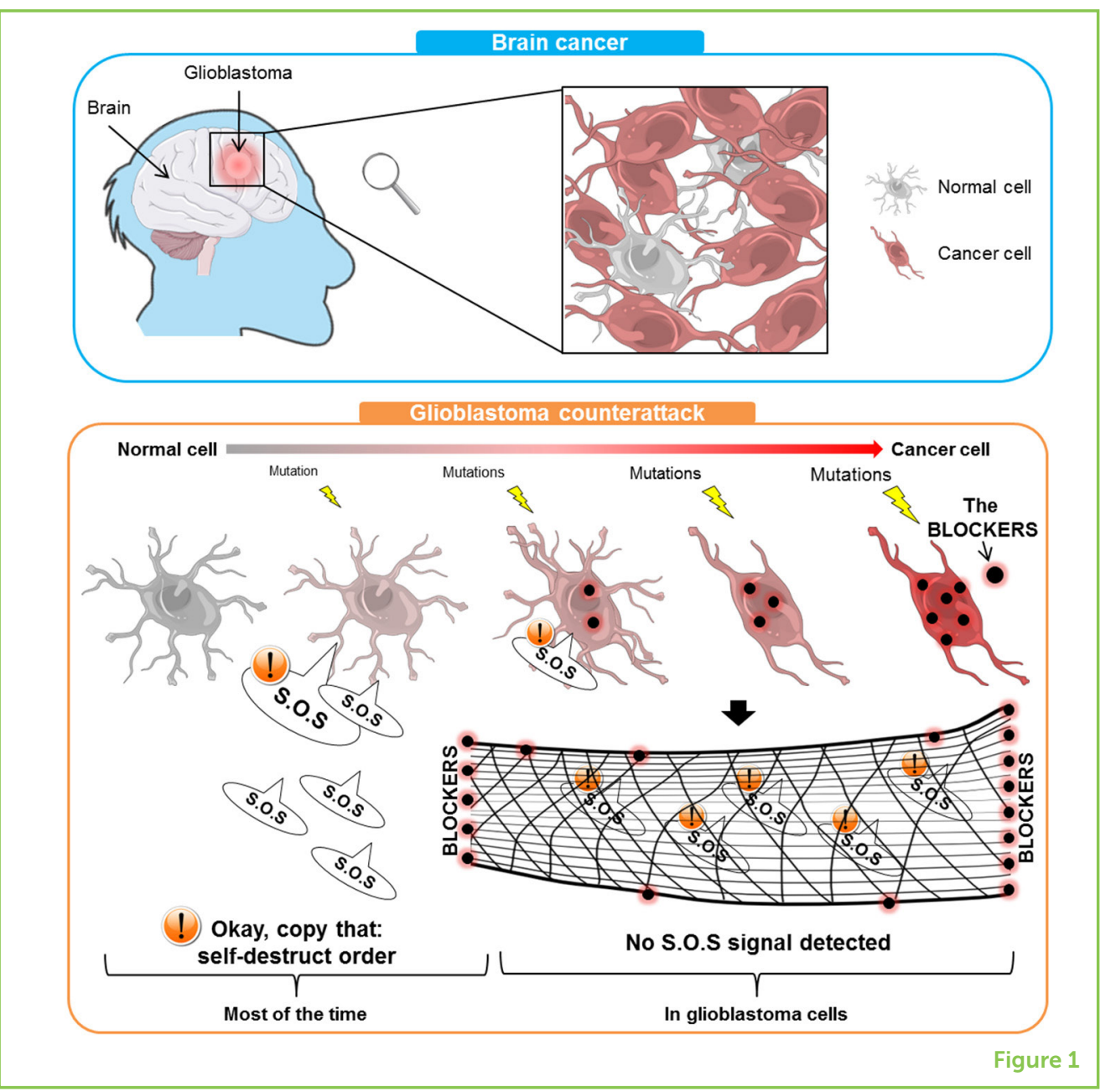

patient, remove the cells from the tumor and provide them with water and food. Once the cancer cells are growing well in the tubes, we can begin to study them and perform the tests with the drug.

First, we studied the effect of the drug on the production of BLOCKERS by cancer cells [3]. Indeed, the drug caused a decrease in the production of BLOCKERS because it bound them and helped the cells to get rid of them. Then, the cancer cells were able to self-destruct. To appreciate the effectiveness of this drug, we had to have a point of comparison. So, we had cancer cells treated with the drug and another batch of cancer cells that we treated with just water (called control cells). We saw that treatment with the drug caused apoptosis in the cancer cells and of course the control cells remained alive (Figure 2).

In a second stage, we carried out the in vivo experiment [3]. Drugs are always tested on animals before being tested on humans and this is called a pre-clinical study. The pre-clinical study is an essential step in the testing of a new drug. The first thing to check, since we wanted the drug to cure a brain disease, was to make sure that the drug went into the brain. 
Figure 2

Top panel: The way the drug works is simple: it captures the BLOCKERS in the cells, like a clothespin, which helps the cells to get rid of the BLOCKERS. When the BLOCKERS have disappeared, cancer cells can self-destruct. Bottom panel: For the in vitro experiments, cancer cells were treated with either water (control) or drug (treatment). After 8 days, we observed the cells in detail. At the end of the experiment, the number of control cells was the same as in the beginning. However, many cancer cells died in the presence of the drug and those that remained had far less BLOCKERS.

\section{BLOOD-BRAIN \\ BARRIER}

The blood-brain barrier is a highly selective physiological barrier in the brain that separates the blood circulation and the central nervous system. It protects the brain from pathogens, toxins and hormones circulating in the blood.

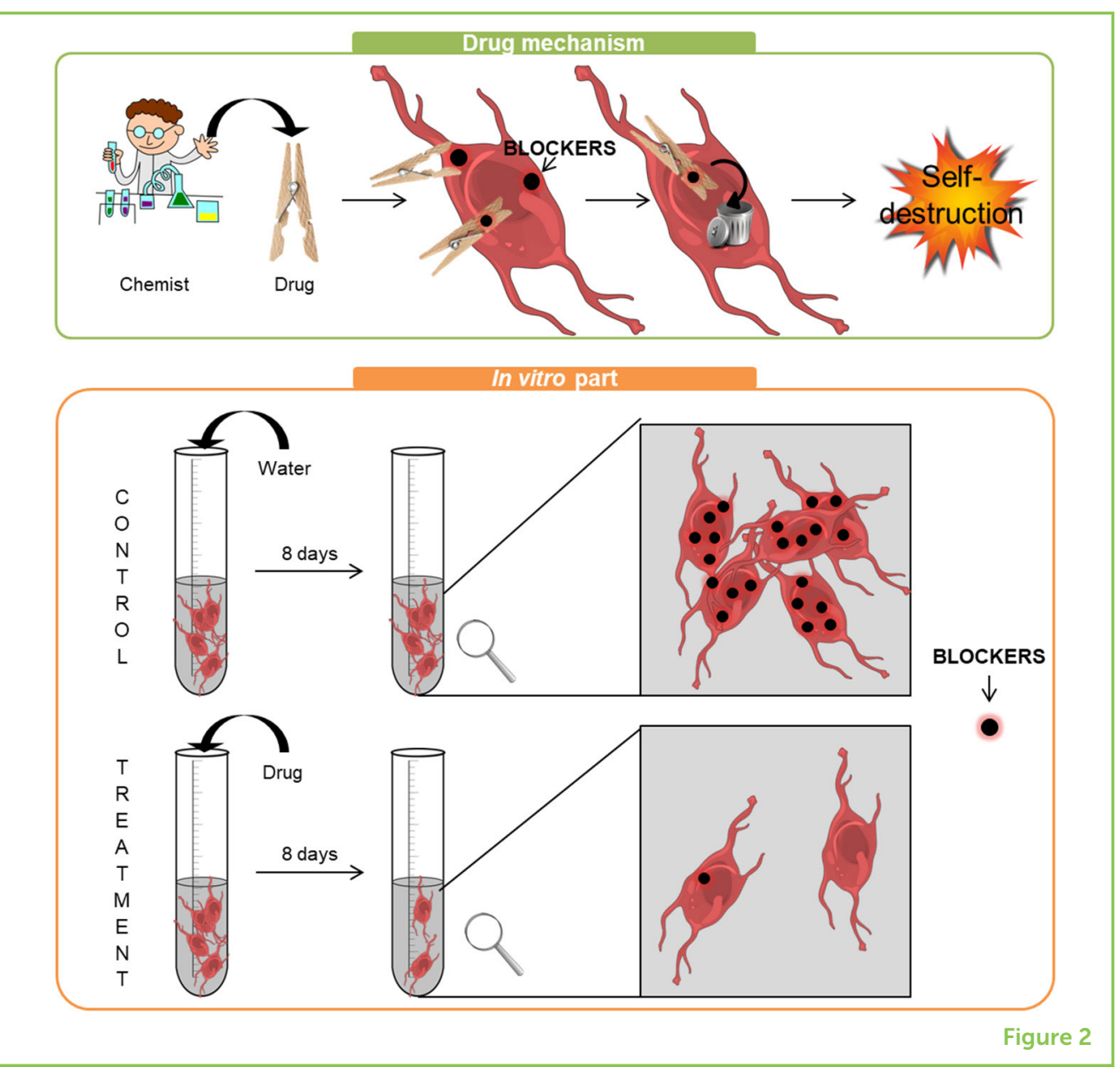

You certainly know that we have blood circulating through our bodies, to provide our organs (liver, lungs, kidneys, etc.) with everything they need. So, if a drug is injected into the blood, we might think the drug will naturally go into all of our organs. But no, our bodies are much more complicated than that. The brain is isolated from the blood circulation by what is called the blood-brain barrier, which prevents viruses, for example, from reaching the brain. The bloodbrain barrier is very effective at protecting the brain from external diseases, like viruses, but the problem is that it also prevents certain drugs from getting into the brain. So, we checked to see that our new drug was small enough to cross the blood-brain barrier and reach the brain, and it was!

Then, the next experiment was to inject glioblastoma cells into the brain of mice, while taking care of their well-being so that they did not suffer. Getting the cells into the brain was an extremely precise surgical procedure that required the animals to be asleep. The cancer cells we injected were special, they were fluorescent red! This allowed us to see them throughout the animal's life. Like humans do after surgery, the mice woke up slowly and quietly resumed their daily lives. 
Three groups of seven mice each were formed. A control group (group 1), a group treated with a low dose of the drug (group 2) and another group with a higher dose of the drug (group 3).

To know if the mice were doing well, we checked their weight and behavior every day. This follow-up allowed us to measure the number of days, weeks, or even months during which the mice lived without suffering from brain cancer.

\section{WAS THE NEW DRUG EFFECTIVE IN PREVENTING GLIOBLASTOMA?}

Our results were very promising: the control group lived on average about 25 days, the second group on average 40 days, and the third group lived longer than 90 days. This told us that the drug slows the tumor growth and that the highest dose is the most effective, allowing mice to live longer.

Other important information was obtained from the red fluorescent cancer cells. We had a special technology that allowed us to see these red fluorescent cells through the skulls of the mice, without hurting them. Once a week, we looked at the progression of brain cancer in all mice. We noticed that all seven of the mice treated with water developed cancer, while five mice in group 2 and only three mice in group 3 developed brain cancer (Figure 3). For the control group, the tumors appeared in the second week after the cancer cells were

Figure 3

For the in vivo experiments, we used mice that had been injected with glioblastoma cells. Here we show the results of group 1 (control) mice, treated with water, and group 3 mice, treated with a high dose of the drug. Once a week we filmed the mice with a special camera that detects the red fluorescent cancer cells. The white arrows point to the tumors and you can see that the tumor appeared later and the size of the tumor was much smaller in the mouse that received the drug treatment. injected, whereas tumors only appeared in the fourth week in mice

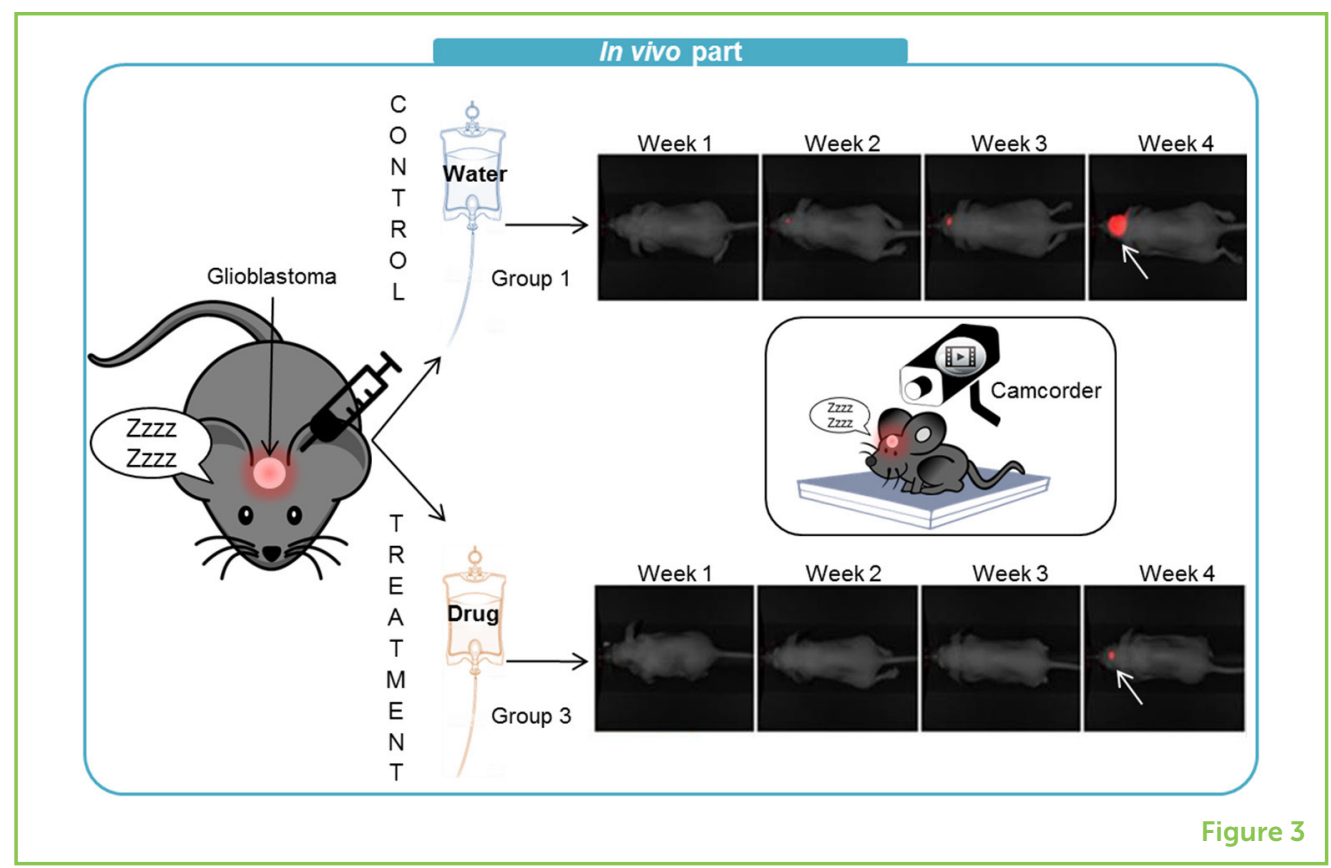


treated with the drug. We also found that mice treated with the drug had much smaller tumors than did the mice treated with only water (Figure 3-see white arrows). This experiment showed that this drug significantly slowed the progression of cancer in these mice. With all these results, we can say that the treatment was effective in animals. There were no side effects detected, even with the highest dose of the drug.

\section{CONCLUSION}

This study allowed us to conclude that the drug we used is a good candidate for treating brain cancer in humans. Indeed, it neutralized the BLOCKERS and caused the self-destruction of cancer cells. Good results were seen in mice with brain cancer, as drug treatment slowed the progression of cancer and, for some mice, it even prevented them from getting cancer. The next step is to test this drug in combination with conventional treatment in order to synergize all the effects of the drugs and hopefully, in the future, cure patients with glioblastoma.

\section{ACKNOWLEDGMENTS}

Images were created using Servier Medical Art under Creative Commons Attribution 3.0 Unported License.

My work was supported by the ARTC Sud French Association (Association pour la Rercherche sur les Tumeurs Cérébrales).

I warmly thank Dr. Céline Caravagna for great help writing this article.

\section{ORIGINAL SOURCE ARTICLE}

Tchoghandjian, A., Soubéran, A., Tabouret, E., Colin, C., Denicolaï, E., Jiguet-Jiglaire, C., et al. 2016. Inhibitor of apoptosis protein expression in glioblastomas and their in vitro and in vivo targeting by SMAC mimetic GDC-0152. Cell Death Dis. 7:e2325. doi: 10.1038/cddis.2016.214

\section{REFERENCES}

1. Louis, D. N., Perry, A., Reifenberger, G., von Deimling, A., Figarella-Branger, D., Cavenee, W. K., et al. 2016. The 2016 World Health Organization Classification of Tumors of the Central Nervous System: a summary. Acta Neuropathol. 131:803-20. doi: 10.1007/s00401-016-1545-1 
2. Flygare, J. A., and Fairbrother, W. J. 2010. Small-molecule pan-IAP antagonists: a patent review. Expert Opin. Ther. Pat. 20:251-67. doi: 10.1517/13543770903567077

3. Tchoghandjian, A., Soubéran, A., Tabouret, E., Colin, C., Denicolaï, E., Jiguet-Jiglaire, C., et al. 2016. Inhibitor of apoptosis protein expression in glioblastomas and their in vitro and in vivo targeting by SMAC mimetic GDC-0152. Cell Death Dis. 7:e2325. doi: 10.1038/cddis.2016.214

SUBMITTED: 27 August 2018; ACCEPTED: 21 February 2019; PUBLISHED ONLINE: 18 March 2019.

EDITED BY: Suzanne Phelan, California Polytechnic State University, United States

CITATION: Soubéran A (2019) Test of a New Drug to Treat Brain Cancer. Front. Young Minds 7:43. doi: 10.3389/frym.2019.00043

CONFLICT OF INTEREST STATEMENT: The author declares that the research was conducted in the absence of any commercial or financial relationships that could be construed as a potential conflict of interest.

COPYRIGHT @ 2019 Soubéran. This is an open-access article distributed under the terms of the Creative Commons Attribution License (CC BY). The use, distribution or reproduction in other forums is permitted, provided the original author(s) and the copyright owner(s) are credited and that the original publication in this journal is cited, in accordance with accepted academic practice. No use, distribution or reproduction is permitted which does not comply with these terms.

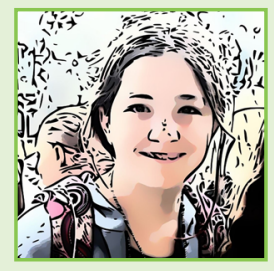

\section{YOUNG REVIEWER}

\section{ELIZA, AGE: 12}

I love to spend my time reading, reading, and reading! When I am not reading, I spend my time playing basketball, swimming, hanging out with my friends, and loving llamas.

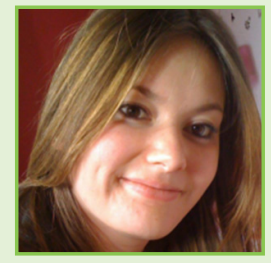

\section{AUTHOR}

\section{AURÉLIE SOUBÉRAN}

I am a post-doc at the Institute of Neurophysiopathology in France. I am particularly involved in my research on glioblastoma because of the lack of effective treatment and because patients expect us to find a solution to improve their living conditions. I also like to develop collaborations to discover new themes and experiences. I think it is essential to open science to the general public and share our discoveries, which is why I participate in several popular scientific events. At home, I love doing pastry and my co-workers love to taste it. *aureliesouberan@ gmail.com 